\title{
O Espaço-Tempo dos Laboratórios na Química Europeia (1789-1939)
}

\author{
A NA L UÍSA J A NEIRA *
}

Olhando à volta, pergunte-se ao acaso: $\mathrm{O}$ que determinará o fazer-querer-saber e o fazer-querer-fazer, nos limites do poder-fazer e nāo-poderfazer,vinculados à organização espacial de um Laboratório de Química?

As zonas onde não se pode passar, quando as há,

como equivalem a não se poder saber o que lá se passa?

De que modo a dinâmica social, inerente ao tipo de relação e de interacções, favorece a constituição de um actante colectivo, a equipa de investigação?

Como é que as regularidades vigentes na Química actual e a configuração epistémica englobante condicionam tudo isto?

Continuando a perguntar: o que foi acontecendo nos Laboratórios de Química da Europa entre 1789-1939? I

A síntese dos textos apresentados no «Workshop on Chemistry Laboratories, Instruments, New Technologies and Spaces (1789-1939)" (Segovia, Cristalera, November 1994) e no "Workshop on Chemistry Laboratories, Instruments, New Technologies and Education (17891939)" (Lisbon, Science Museum of the University of Lisbon, November 1996) ${ }^{2}$, pretende situar os principais aspectos relevados na produção do discurso, quando se visam os laboratórios numa perspectiva espáciotemporalizante, ou seja, como espaços fundamentais, complexos e dinâmicos, no interior da Química correspondendo a uma configuração geográfica e histórica bem delimitada e precisa: a Química na Europa entre 1789-1939.

Logo, os laboratórios surgem como um conjunto de termos integrados num determinado sistema de relações, e abrigam ainda lugares próprios, de índole vária (agentes, equipamento, funções, etc.), tudo isto inserido num processo temporal. Assim sendo, o topos estabelece relações privilegiadas com o logos, de onde retira, aliás, as suas condições de existência e de transformação. Por isso, quando acontecem mudanças no topos é preciso situar as alterações no logos.

Sendo que as unidades espaciais funcionam como relações entre termos (diferença, distância, oposição, proximidade, semelhança, convergência, filiação), há ainda a distinguir ritmos e sequências dominantes, tendo presente quanto o construído é uma, entre outras formas, incluindo formas precisas de relacionamento interpessoal.

Além disso, o pressuposto de que estes lugares não terão revestido sempre as mesmas concretizações, nem os mesmos sentidos, implica especial atenção às descontinuidades associadas às mudanças ocorridas nos sistemas epistémicos. Neste sentido, a hipótese de que os laboratórios materializam condições de possibilidade inerentes à lógica da Química que os suporta, sendo por ela sobredeterminados, determina este processo: das espacialidades passa-se às regularidades químicas inerentes, e procurando os sistemas configurantes, por fim.

Simultaneamente, por que recobre conhecimentos onde o saber é transformado em fazer, mediante formas de saber-fazer, importa perceber como se efectua a aprendizagem ao nível do ensinado e investigado (transmitido pelo dizer e(ou) apreendido através da prática).

É preciso reconhecer os papéis assumidos pelos dispositivos espaciais (síntaxe) e o significado do investimento nos lugares (semântica). Isto é, aceitar que a manifestação discursiva permite detectar valores e suas alterações, porquanto os efeitos do sentido são reveladores de um sentido e as manifestações apontam para estruturas subjacentes e dinâmicas.

Com efeito, segundo esta concepção teórica, a sintaxe materializa a semântica, reactivada aqui e agora pela aç̧ão (dimensão imanente) e a semântica integra determinações ci- entíficas, associadas a outras de natureza social e cultural pré-existentes (dimensão transcendente). A análise sintática conduz ao semantismo do discurso, enquanto que a análise semântica vai identificar o recebido, $a$ priori.

O laboratório concretiza, pois, e muito especialmente, regras e regulações decorrentes do conceito de Ciência, nomeadamente da Química, e do modo como são consideradas as tensões entre teoria e prática ou entre áreas disciplinares que nele coexistem e predominam, e a lógica da sociedade onde está inserido.

Veja-se, seguidamente, o que a produção do discurso oferece no interior destes textos, quando se segue este modelo descritivo. Ou seja, como enuncia a mudança nos dispositivos espaciais, as regularidades químicas e os sistemas epistémicos.

\section{ESPAÇOS}

\section{FORMAS RELEVANTES}

NAS DESCRIÇÕES ESPACIAIS DOS LABORATÓRIOS DE QUÍMICA $\longrightarrow 1830 s$

\section{ORIGEM}

- evoluindo de cozinhas, oficinas, forjas (Knight) e espaços de tradição alquímica (Costa)

- espaço adaptado (Lico) ou criado de raiz (Ferraz)

realidade laboratorial concreta desarticulada do discurso legislativo (Lico, Maia)

SUPERFICIE

- pequena e média escala

- constituído por uma só, pequena ou grande sala (Knight), ou até mais (Seligardi $\mathrm{l}^{3}$ )

- tendo associado um apartamento (Bret) ou anfiteatro (Rambaldi)

SITUAÇÃO

- lugar privado ou público, situado em casa particular ou palácio académico (Dolza, Brooks)

- portátil (Knight)

DESTINO

- vocacionado para abrigar operações químicas e servir para reserva de colecções e equipamento 
(Bret), semelhante a espacialidades da História Natural - museu (Ferraz)

- usado para preparação de demonstrações experimentais apresentadas durante as lições (Rambaldi), para averiguações e aplicação de conhecimentos e produção de reagentes ou medicamentos (Ferraz), semelhante a espacialidades da Farmácia - botica (Meinel)

- ligado a interesses militares

- demontrando separação entre teoria e experiência (Ferraz)

- ao serviço de projectos individuais (Seligardi 1) ou colectivos

DESCRIÇÃO EM

- livros e revistas (Knight)

\section{FORMAS RELEVANTES}

NAS DESCRIÇÕES ESPACIAIS

DOS LABORATÓRIOS DE QUIMIICA

1830 s-"

\section{ORIGEM}

- edifício antigo (Gavroglu) ou novo, com hall imponente e esplêndida sala de baile (Meinel), possuindo apartamentos para o director (Meinel) e professores (Brooks), e ainda salas técnicas (Meinel)

SUPERFÍCIE

- média e grande escala (Bret)

SITUAÇÃO

- público (Janeira) ou semi-privado (Faulque), nacional (Bret)

DESTINO

- orientado para o ensino - industrial (Cruz) ou universitário (Filgueiras) - com capacidade para acolher alunos (Pigeard), separado (Gavroglu) ou não do laboratório e demais salas para professores (Maia)

- abrigando investigação original (Gavroglu), passível de se organizar em programas e grupos (Meinel), identificado com um centro de investigação (Ordoñez), ligado a experiências profissionais (Cruz), associado à indústria em geral (Faulque) ou à indústria química em particular (Meinel), e ao controle de qualidade (Bret)

ESPECIALIZAÇÃO

- individualizado por servir a Química Geral, Química Mineral, Química Orgânica, Química Orgânica

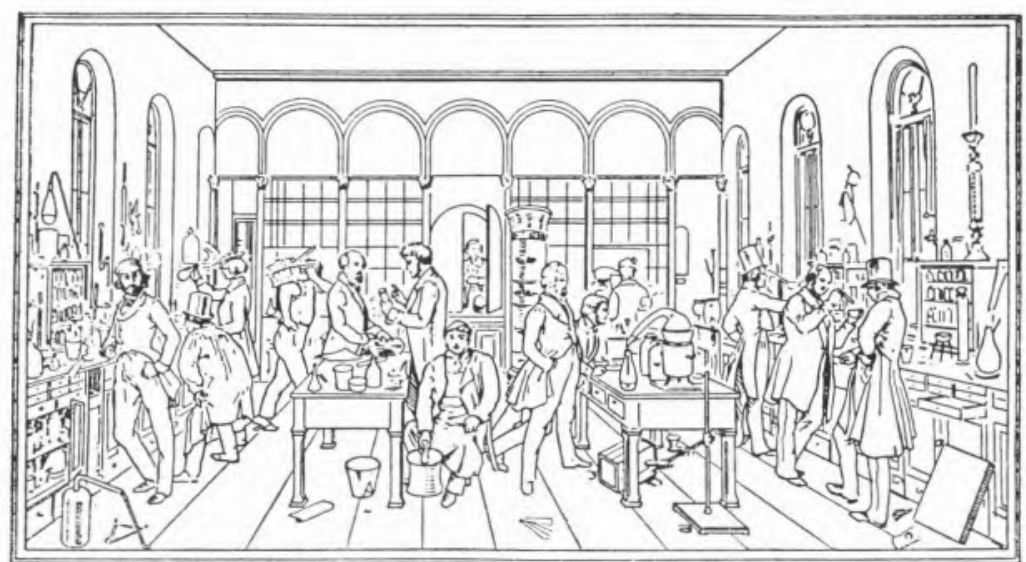

Fig. 1 - O Laboratório de Liebig em Giessen (1842)

Aplicada à Fisiologia, Química Biológica, Análise Qualitativa e Quantitativa (Faulque)

DESIGNAÇÃO

podendo já ser chamado de Instituto (Meinel)

DESCRIÇÃO EM

- relatórios (Faulque) e manuais para o ensino secundário (Lico)

\section{CHEMICO-PHARMACEUTICAL INSTITUTE, GIESSEN Justus Liebig}

- «primeiro a considerar a prática laboratorial como essencial no ensino da Química na universidade” (Kritsman)

- " (...) isolamento prático de compostos químicos purificados a partir de substâncias naturais; (...) estudo dos métodos de análise elementar de substâncias naturais e compostos orgânicos; (...) estudos das propriedades químicas de compostos químicos extraídos e suas reacções (...) trabalho científico independente em Química Orgânica” (Kritsman)

- o aluno passa a poder executar trabalhos que necessitavam de pessoas experimentadas até então, isso acontecendo porque se seguem " métodos de rotina mais eficientes, rápidos e mais dignos de confiança para determinar a composição de uma substância dada, através da análise gravimétrica dos produtos da sua combustão" (Meinel)
- o director projecta e controla o plano geral, reúne e interpreta dados finais; com os investigadores, dedica-se à vertente de investigação: alunos e amanuenses executam o trabalho rotineiro das composições elementares; logo, a divisão do trabalho entre director, investigadores, funcionários e alunos cria condições de possibilidade para a existência de um grupo de investigação (Meinel)

- o instituto de investigação segue o modelo de uma fábrica (Meinel)

\section{EQUIPAMENTOS}

\section{LUGARES EMERGENTES \\ NAS DESCRIÇÕES}

DOS LABORATÓRIOS DE QUIMICA

$\longrightarrow 1830 \mathrm{~s}$

"We can find more details in a general inventory of 1797. The cabinet consisted in two rooms. In the first room there were about 18 pieces of glassware and one chemical furnace; in the second room there were 13 furnaces, devoted to different chemical operations; moreover, there were two mortars, a grinder, 85 pieces of glassware, but only one scale." (Seligardi 1)

"A l'occasion de ces mentions d'expériences ou lors de la description des pratiques du métier, plusieurs instruments de laboratoire sont cités dans ce project de dictionnaire. La seule mention explicite d'une balance 
concerne l'essai du salpêtre pour mesurer son titrage en salpêtre pur, mais les tableaux indiquant des poids et volumes disent bien son usage généralisé et celui du gazomètre - non explicitement mentionné - dont Mégnié construisit un second modèle por Lavoisier entre 1785 et 1787 . Ce dernier fait en revanche des références explicites à l'emploi du verre ardent, du fourneau à réverbère, de cornues de verre et de porcelaine. Et si le calorimètre est également absent, il l'a pourtant utilisé pour étudier la "détonation" (déflagration) du nitre, avec le charbon d'une part, avec le soufre d'autre part, sans que les produits de ces réactions fussent ensuite analysés, laute d'avoir récupéré les gaz.

L'instrument privilégié dans cette série d'articles est l'aréomètre, dont on connaît l'importance chez Lavoisier. Devenu l'instrument obligé non seulement des laboratoires associés aux raffineries de la Régie, mais aussi des ateliers de salpêtriers, il est à ce titre le seul instrument qui fasse l'objet d'un article séparé du projet d'Encyclopédie méthodique, ou il est considéré davantage comme un instrument de contrôle professionnel que comme un instrument de laboratoire. Mais cet instrument-roi de la rationalisation des méthodes de fabrication de salpêtre, fabriqué exclusivement par le constructeur d'instruments scientifiques de l'Académie des sciences, Mossy, est sans doute à la fois le premier instrument passé du laboratoire académique à l'atelier industriel et le premier instrument étaloné et dûment garanti par une institution relevant de l'État, la Régie des Poudres et Salpêtres. En ce sens, il est le symbole précurseur d'un transfert appelé à se développer." (Bret)

"Le laboratoire de Brianchon occupe, au rez-de-chaussée de l'un des pavillons du château de Vincennes, deux pièces contigues, assez "spacieueses pour les travaux particuliers d'une école d'artillerie", avec une porte de communication.

La première salle, une pièce presque carrée (env. 655,5 m²) "spécialement destinée aux opérations chimiques", comprend l'ensemble des fourneaux. Le sol en est pavé, et quatre fenêtres assurent à la fois l'éclairage naturel et une bonne aération en cas de dégagement accidentel de vapeurs nuisibles.

Son organization est fondé sur le système de ventilation par cheminées d'appel "employé si heureusement par M. Darcet, pour assainir les forges des doreurs, les cuisines, les soufroirs et les latrines" et au laboratoire des essais de la Monnaie. Darcet lui-même en a réglé "toutes les dispositions". Au mur de séparation entre les deux salles s'adossent les fourneaux pratiqués dans une paillasse en briques, dans le prolongement de la porte de communication. Ils sont recouverts par la hotte du manteau de la vaste cheminée principale, qui reçoit les quatre cheminées particulières. La clef du système est le fourneau central: la porte de son cendrier fermé, il sert de fourneau d'appel car il dispose d'une cheminée spéciale qui, partant du cendrier, permet une combustion à flamme renversée destinée à échauffer la partie supérieure de la cheminée générale pour en activer le tirage. Une fois assuré le tirage régulier par les quatre systèmes d'appel secondaires il peut être utilisé comme un fourneau évaporatoire normal.

Dans le fond de l'âtre sont suspendus des couvercles convexes qui servent, selon le sens où on les pose sur les fourneaux, d'etouffoirs ou de bain de sable, sur le flanc gauche de la paillasse, jouxtant la porte de communication, se trouve le "fourneau à vent" ou fourneau de fusion à haute température, servant "notamment pour les travaux de métallurgie et les essais docimastiques". Au flanc opposé, un autre fourneau dispose d'un "bain de sable" à double bac, "ce qui donne deux profondeurs de sable, appropriées aux diverses capacités des matras qu'on y met en expérience". Dans le coin voisin se trouve le "fourneau d'alambic, où se fait la distillation de l'eau". Outres deux grandes cavités basses servant de charbonniers, la paillasse elle-même comprend une forge à soufflet, quatre fourneaux évaporatoires, une étuve et un fourneau d'étuve chauffant également une grande plaque de fonte pour faire sécher les filtres.

L'équipement du laboratoire comprend encore une fontaine dans un coin, à côté d'un égouttoir "formé d'une planche horizontale percée de trous", un évier "dans l'embrasure d'une croisée", une enclume, un établi avec un étau dans l'embrasure voisine, une lampe d'émailleur et un fourneau mobile en terre cuite. L'ameublement se compose d'un placard, d'une armoire et d'une table. Des "cuves pneumato-chimiques", des terrines, creusets et vases, tous ustensiles non métalliques, sont à demeure dans la pièce, disposés sur l'entablement du manteau de la cheminée et sur le cours de tablettes situé au dessus, ou rangés à même le sol sous l'égoutoir.

Tout le reste du matériel prend place dans la seconde salle, au sol en parquet. Plus petite (env. $653,5 \mathrm{~m}^{2}$ ), elle "renferme les collections, les balances, les machines, les ustensiles métalliques et les instruments de prix", qui devaient rester à l'abri de I'humidité et des gaz corrosifs du laboratoire lui-même. Ecclairée par une fenêtre unique, elle comporte aussi un "vasistas" carré un hauteur (2,5 $\mathrm{m}$ du sol), "pour établir un courant d'air, ou pour déterminer le tirage du poêle". Ce dernier, "dont le recouvrement est creusé en bain de sable, et dont le four sert d'étuve", est un élément important du dispositif général puisque, à travers le mur de séparation, son tuyau d'évacuation "débouche en un point élevé de la cheminée générale du laboratoire, dont il avive le tirage en y raréfiant l'air par la chaleur qu'il apporte". L'ameublement se compose, outre un large cours de tablettes d'appui, d'une table à tiroirs et de deux armoires vitrées à portes coulissantes. Le contenu de ces dernières - pompes pneumatiques, instruments de mesure (balances, aréomètres et eudiomètres assurément, gazomètre peut-être), etc. - n'est malheureusement pas détailler par l'auteur." (Bret) 
"W. T. Brande in his Manual of Chemistry has a splendid fold-out frontespiece of the Royal Institution's Laboratory (now a museum); and he also shows as plate I a portable laboratory for the analysis of mineral waters; but the plate appears to be an extra one, and there is no description to accompany it. It includes a box with stoppered bottles of reagents, standing above a bigger box or deep tray with various vessels, spirit lamps, a thermometer, one of Wollaston's slide rules for computing equivalent weights, calipers and tongs, filter funnels, blowpipes and retort stands. It would clearly have been useful to anybody doing any kind of chemistry. The plate bears the signature M F delin.; it would be nice to think that Michael Faraday did it."

(Knight)

"A notion of the most necessary furniture of a small laboratory, or of one to be comprised, in cases of necessity, on the surface and within the drawers of a single table, may easily be gathered from the manipulatory parts of the present work. If the want of time, or other circumstances, should necessarily limit the chemical pursuits, the author would advise a person so situated to begin by providing a spirit-lamp, a pair of pliers, some platinum foil and wire, a platinum capsule, a few Florence flasks, a chemical lamp, a few evaporating basins, a few pieces of quill glass tube, and two or three dozen bottles; with some of the most useful chemicals, as the acids and alkalies, and six or eight of the most important tests; and to purchase another things as the necessity for them may arise."

(Faraday apud Knight)

"An important part of Faraday's apprenticeship has been his visit to France, with Davy and a portable laboratory, in 1813 . He reports their work on what Davy was to christen "iodine", writing on 23rd November that "Sir Humphry Davy made various experiments on it with his travelling apparatus": these included volatilizing it, dissolving it in alcohol, rubbing it with zinc filings, heating it with potassium, then with phosphorus, and finally with mercury. On Ist December we learn more about experiments Davy had been doing on that and the previous day; but on 3rd December they went to M. E. Chevreul's laboratory at the Jardin des Plantes (where Faraday was not much impressed with the facilities) to do more work. One could not do everything with a portable laboratory; on 11th December they borrowed a voltaic pile from Chevreul.

At Montpellier on 2nd February 1814 Davy is reported as having been working further on iodine. analysing Mediterranean plants. In Genoa on 4th, 5th and 6th March they examined and dissected torpedoes; but in Florence they used the laboratory of the Accademia on 2 lst March and subsequent days, when Davy burned a diamond. They did the same in Rome on 16th April: on 26th October when they analysed some gas bubbling up from the ground, they did it "at home" and thus with the portable laboratory." (Knight)

\section{LUGARES EMERGENTES \\ NAS DESCRIÇÕES}

\section{DOS LABORATÓRIOS DE QUIMICA} 1830s-"

"In a letter from Montignoso (22 February 1852) Bertagnini wrote to Cannizzaro: "I easily imagine the numberless difficulties that you must have overcome in the establishing of a Lab., being in a town where there is nothing, and nobody is found". Actually by then Cannizzaro', laboratory was in almost full order. He had a chemical laboratory divided in three rooms: one for the preparation of the experimental demonstrations for the lessons, one for the personal work, and the last one for the chemical preparation. The balance and the pneumatic machine were in a clear and dry room, that sheltered the machines (macchine) of physics." (Rambaldi)

«... Massimo D’Azeglio, a pro- tagonist of the political life in the Kingdom of Sardinia. The private laboratory of Bertagnini had only very poor furniture, no more than a few cases that had been used for the transport of the chemical products in that retired spot of the chemical world, but, when Cannizzaro returned in Alessandria, so far from his own family and Country, he felt in a dramatic way the nostalgia of Montignoso."

(Rambaldi)

"Now we know exactly the stock on hand of Cannizzaro's laboratory at the end of his mandate in Genoa, in fact it has been luckily recovered the inventory of the laboratory of General Chemistry, compiled by professor Finollo, the successor of Cannizzaro on the Genoa Chair, when assumed the responsibility of the whole equipment. In the inventory the different kinds of objects are listed with great precision: pieces of furniture, books, instruments, gas and coal stoves, tools in platinum and silver, glass-ware, chemicals, and so on; For any item it is reported a number of pieces. By confronting this inventory with the purchase bills sent by the firms producing the apparatus and the laboratory tools, it has been possible to get a picture of the instrument equipment of the laboratory wanted and directed by Cannizzaro in that period. Moreover, the recent retrieval in Alessandria of book-keeping documents relative to Cannizzaro's activity shows further on, and confirms, the typical implements of a middle nineteenth century chemical laboratory. We find not only phials, funnels, flasks, gres ritorts, Warrentrap's tubes, Drummond's burners, Volta's eudiometers, etc., but also a remarkable variety of chemical products with the relative quantities present in the laboratory. The documentation found in Alessandria has given also the names and the specialisation of some supplying firms (Lizè \& Clech, Charle Jest, Domenico Marcellino), and it has confirmed the specialisation of Giuseppe Buscaglione that in his headed paper defined himself "master 


\author{
"Inventory of jewels, effects and furniture of this literary university \\ and inventory of didactic materials of laboratories and departments. 1850 \\ Objects of Chemistry department \\ (Laboratory and porter's office)
}

204 different sizes glass retorts

40 different sizes clay retorts

15 porcelain retorts

1 iron retort

27 glass adapters

10 still head (called More's head)

93 different sizes three-necks flasks

400 wide-necked bottles

200 different sizes narrow-necked bottles

2 measuring matrasses (one litre)

353 different capacities matrasses

76 different sizes glasses

(some of them with spout)

11 bottle (with a neck S-bend)

21 different sizes glass funels

7 porcelain mortars

1 marble mortar

(Edreira)

\section{2 airon mortars}

10 different sizes bell jars, to collect gasses

12 bent tubes with glass balls

53 safety S-bend tubes

5 double siphons

4 water pneumatic tanks

45 different sizes porcelain recipients to evaporation (10 of them with handle)

18 reverberator kilns

3 copper stills (with their boilers)

13 different sizes pans

1 bellows

1 box with different sizes cupels

2 Volta dry cells

2 balances

1 enamelled lamp pectivement à chacune des trois catégories d'élèves, les débutants, les élèves plus avancés puis les jeunes chimistes. C'est dans le troisième que s'effectuent les véritables recherches; Il est bien différent des laboratoires d'enseignement. Chaque salle possède dix tables accueillant chacune deux "pratiquants ". Chaque table possède des tiroirs pour receler les objets appartenant aux élèves et fermant à clé ainsi que des armoirs sur les côtés. Il existe une niche pour l'évaporation creusée dans l'épasseur du mur. La division en trois grandes salles permet une surveillance plus facile, et la mise à disposition des ressources spéciales qu'exige le genre particulier de travail auquel l'élève se livre.

Outre les salles d'experiences, le laboratoire comporte des salles réservées aux grandes opérations et qui requièrent des appareils compliqués. Il existe aussi des salles spécifiques. Une salle de cours de 200 personnes contient trois tables d'expérience avec tiroirs et armoires et un laboratoire annexe donnant sur cette salle par une ouverture dans le mur. Des niches sont creusées dans le mur pour l'évaporation; des rails permettent d'amener une table chargée de matériel dans la salle de cours, qui n'est pas un amphithéâtre. Il existe aussi un cabinet de conservation d'objets divers (instruments, modèles, tableaux, collections.

Enfin, une bibliotèque est mise à la disposition du personnel et des élèves. Wurtz est frappé par la qualité recherchée dans l'admission de la lumière, dans l'éclairage en général, dans l'aération des locaux, par l'aspect fonctionnel des differentes parties du bâtiments. Tout est fait pour que ceux qui le fréquentent s'y sentent bien. La structure des autres laboratoires modernes est basée sur le même principe. Pour Vienne dont la disposition d'ensemble est semblable à celle de Bonn, Wurtz détaille la fonction d'une série de petites pièces situées entre deux salles. Chacune a une destination spécial en rapport avec les travaux qui doivent être exécutés dans les grands laboratoi- 
res. Ainsi d'un côté, une chambre pour les balances, une chambre pour les analyses organiques; de l'autre, une pièce pour l'hydrogène sulfuré, une autre pour les analyses spectrales, une troisième pour les analyses de gaz; au milieu, une bibliothèque. On reste confondu devant une telle abondance de réalisation de rêves d'expérimentateurs chimistes." (Fauque)

"For example, the Central Chemistry Laboratory of the Ministry of Finance was asked by the Supreme Commander of the Medical and Evacuation Forces in March 1916 whether this laboratory could prepare needed medical and pharmaceutical supplies. The Director of the laboratory responded:

We are experiencing a very difficult time with respect to the lack of materials and equipment. We have spent nearly the entire time after receiving your request in the search for the materials needed to prepare these supplies. It turned out that it was simply impossible to acquire many compounds, while we were not able to purchase others due to their extremely high price. We can prepare supplies containing iodine or silver only if we are given iodine or silver."

(Brooks)

\section{REGULARIDADES QUÍMICAS}

REGRAS LEGITIMANTES

NAS DESCRIÇÕES DISCIPLINARES

DOS LABORATÓRIOS DE QUÍMICA

$\longrightarrow 1830 s$

\section{CONTEXTO DISCIPLINAR}

- Química ao serviço da História Natural, Medicina e Farmácia (Ferraz)

- Química dos Gases

- fronteiras ténues entre Química e Física (Seligardi 1) modelo: Física Experimental de Newton (Ferraz)

- separação entre teoria e experiência (Filgueiras)

OPERAÇÕES

- análises e sínteses, predomínio de análises (Dolza, Mierzecki): águas, etc (Ferraz)

\section{APLICAÇÕES}

- Química relacionada com interesses militares (Bret) e docimásia (San Filippo)

- Química aplicada às Artes e Ofícios (Lico): salitre, pólvora, tinturaria, aclimatação de plantas (Giormani)

- Química útil ao progresso (Filgueiras)

\section{REGRAS LEGITIMANTES}

NAS DESCRIÇÕES DISCIPLINARES

DOS LABORATÓRIOS DE QUIMICA

$1830 \mathrm{~s} \rightarrow "$

\section{CONTEXTO DISCIPLINAR}

- Química Orgânica (Fauque)

- "os resultados analíticos mudam de sentido", o "argumento químico" passa a significar "caracteres numa linguagem de fenómenos" (Meinel)

- Pesos Atómicos (Aragón de la Cruz)

- Espectroscopia (Aragón de la Cruz) TEORIA E PRÁTICA

- sobre(des)valorização da teoria face à prática: teorismo ou experimentalismo (Fauque)

- atomismo ou não-atomismo, organicismo ou não-organicismo

- dificuldades perante a vertente teórica (Rambaldi)

- possibilidade teórica de prever compostos (Meinel)

- novos materiais (Meinel)

- importância do modelo alemão (Seligardi 2)

- instrumento como veículo para a recepção de um novo campo científico, seu papel na recepção de inovações por parte de uma comunidade periférica: caso da radioactividade (Palló)

- emergência de escolas (Costa, Pigeard)

\section{QUÍMICOS}

- sentido da identidade profissional (Brooks), o perito (Ramuni)

- primeiros engenheiros químicos (Bret)

- presença de mulheres

- importância das viagens e estadias de estudo (Lico, Ordoñez)

RELAÇÕES COM A INDÚSTRIA

- nova forma de aliança (Meinel) ou conflitos entre instituições de ensi- no-investigação e indústria (Cruz)

- no caso das medidas de precisão, devido à necessidade de cada aluno manipular, o ensino da Física retira da Química formas de aprendizagem por prática directa (Brock)

\section{SISTEMAS EPISTÉMICOS}

\section{CONFIGURAÇÕES SIGNIFICANTES}

NAS DESCRIÇÕES GLOBAIS

DOS LABORATÓRIOS DE QUIMICA

$\longrightarrow 1830 s$

\section{SOCIEDADE E ECONOMIA}

- sociedade rural (Lires)

- o mercado nacional está habituado a comprar no mercado internacional, por isso não resulta fabricar produtos para a indústria local (Ferraz)

- POLÍTICA

- vicissitudes políticas e económicas acabam com os avanços científicos (Filgueiras)

\section{CONFIGURAÇÕES SIGNIFICANTES}

NAS DESCRIÇÕES GLOBAIS

DOS LABORATÓRIOS DE QUímICA

1830 s -

\section{SOCIEDADE E ECONOMIA}

- segunda revolução industrial

- profissionalização (Brooks)

- associativismo (Brooks)

POLÍTICA

- situação de periferia ou de centro (Brooks, Galló, Rambaldi)

- repressão e ocupação políticas agem sobre o movimento científico (Mierzecki, Salkauskas)

- desequilíbrio entre o discurso legislativo e a realidade laboratorial (Lico)

CULTURA TÉCNICA E CIENTÍFICA

- transferência de conhecimentos a nível nacional e internacional; interacções microsociais entre cientistas e relações macrosociais com comunidades mais alargadas (Rambaldi)

- influência das Grandes Exposições e Museus (Rambaldi, Cruz)

- as guerras ganham-se porque se sabe mais (Brooks, Ordoñez)

- influência da Alemanha (Seligardi 2) 
PENSAMENTO

- humanismo contra cientismo (Lico)

- conceito de Bildung definido por Humboldt (Meinel)

\section{CONCLUSÃO}

\section{$\rightarrow " 1830 s$}

Afastada a harmonia pré-estabelecida entre sujeito e objecto do conhecimento, em vigor até ao Renascimento, os fenómenos naturais passam a estar integrados em representações com estigmas de finitude. O nexo entre significante e significado procura superá-los, entrando por esquemas e mecanismos, onde culminam desafios impositivos e controversos na articulação do homem com a natureza.

Assim, a partir de então, mas com maior incidência depois do século XVIII, findas as harmonias e as analogias para sempre perdidas, a razão estabelece uma distância ambígua com a natureza e até com a humanidade. Por isso, fala de um pólo subjectivo valorado, mas coloca um referente objectivo marcado por inacessibilidades, no seu limite.

Esta situação favorece a necessidade de colmatar incertezas por mecanismos de segurança, procurados nomeadamente por via do conhecimento científico.

Na sua globalidade, o pensamento setecentista acordou um lugar especial ao conceito de ordem. Na verdade, as figuras (filosóficas, científicas, artísticas) que emergem estão sempre associadas a ideias relacionadas com marcha ou combinatória, dado que: há necessidade de expressar a sucessão, o encadeamento e hierarquias entre dados sensoriais ou imagens, e é preciso exprimir o sistema, a subordinação e a classe entre os seres.

Por isso, os naturalistas enchem as suas descrições e análises com frequentes pormenores, visando estabelecer regras e dependências entre estruturas lógicas e processos de conhecimento, no interior dos três reinos. Por isso, os enciclopedistas dão a conhecer as cadeias entre acontecimentos passados e os mecanismos perceptivos que condicionam o nosso relacionamento com o mundo exterior.

Neste contexto global, o primado da Metafísica dos factos e das relações materiais (Bacon, Locke, Condillac) sobre a Metafísica do espírito e causas últimas (Descartes, Leibniz), por um lado, e o primado da Gnoseologia sensualista e empirista em desfavor do essencialismo e racionalismo, por outro, condicionam uma lógica individualizada: a representação inclui regularidades entre a ordem do conhecer (observação) e a ordem do ser (fenómeno), entre a ordem do sentir (sensação) e a ordem do pensar (indução). Se perspectivarmos os jogos do entendimento, no interior de uma dialéctica com dois termos - objecto do conhecimento e sujeito do conhecimento - poderemos estabelecer, ao gosto da época, intenções que procuram sistematizar números e cálculos ou coordenar sinais de semelhança e diferença.

A correspondência entre as formas e lugares dos espaços, bem como as regularidades químicas analisadas até 1830 s são possibilitadas pelo sistema epistémico que passo a definir: a ordem da ciência tem de se basear na ordem da natureza, e esta precisa de ser experimentada; a articulação entre fenómenos (natureza) e ideias (ciência) pressupõe uma articulação entre análise e síntese (método), precisão e exactidão, usando balanças; o saber químico pressupõe um léxico disciplinar, impondo ensino e aplicabilidade social.

A seguir, o sistema epistémico veícula, pelo que nega (perspectiva negativista) e propõe (perspectiva positiva), um descrédito face à erudição livresca e uma expectativa prestigiante perante as ciências experimentais. Para tal entusiasmo concorrem principalmente o lugar ocupado pela Física e a importância atribuída aos novos aparelhos e técnicas.

Apesar do fulgor remanescente de Newton e Lavoisier, assumidos através das teses experimentalistas, e defendendo ideias transformadoras, continua a manter-se um debate de fundo, muitas vezes adiado, nomeadamente nas instituições universitárias: qual é o lugar da teoria e da prática no avanço do método experimental? qual é a importância dos $a$ priori e dos a posteriori na teoria do conhecimento?

Prova disso, é o facto da valorização laboratorial e da experimentação não levar a manipulação química aos alunos. Basta-lhes olhar, observar e ver, de longe. O ensino está consignado ao anfiteatro e é marcadamente descritivo. Continuam sem beneficiar do período crítico de Kant, nomeadamente na definição do juízo sintético a priori, que colocou a questão e o debate no seu devido lugar.

É neste contexto, onde predominam ainda resquícios de debates entre fisiocracia e mercantilismo, que a Química começa a revelar-se capaz de contribuir, também ela, para organizar, controlar, gerir, capitalizar o espaço e o tempo requeridos pelo assumir da modernidade.

\section{$1830 s-"$}

Na sequência de um processo onde a razão e a ciência procuram desde sempre formas de optimização, os percursos englobantes do avanço científico e industrial criam condições e requerem meios, para compreender o grau de maturação de certos discursos ou para legitimar a emergência de outros.

Com efeito, seja porque as ciências exactas e experimentais atingem características de previsão e aplicabilidade, seja porque as ciências sociais e humanas já balbuciam dificuldades de existência, o imperativo de as fundamentar assume formas novas e peculiares, desde o século passado. A circunstância geral é promissora de mais saber e poder no futuro. Todavia, os tempos comportam sucessos e indecisões. Humanismo contra cientismo, até.

O impacto das ciências, técnicas e tecnologias implica o modo como elas recebem, concretizam e transmitem pelo ensino e investigação determinados valores, de acordo com as circunstâncias materiais onde se 
constróem e os efeitos sociais que têm em vista, no decurso da sua evolução interna, ou de mudanças para o exterior do universo teórico e experimental. O progresso é aferido em termos optimistas. A pertinência desta forma de enquadramento acentua problemáticas associadas a fins cognitivos e pragmáticos, interesses económicos e políticos, meios institucionais e grupais, com implicações no universo axiológico e ético.

Por um lado, adquiridos espectaculares.

Por outro, complexidades cada vez maiores.

Ligada ao transcendentalismo kantiano e ao idealismo alemão sequente, a teoria é valorizada, enquanto que os mais ligados ao positivismo apregoam a matriz experimentalista. Grandes guerras.

Tornar visível e perpetuar o êxito, expô-lo com majestade plástica, corresponde a uma configuração, onde as retóricas do saber e do poder protagonizam opulência. Mostrar ciências, técnicas e tecnologias com visibilidade espectacular, produtos bem sucedidos e efeitos sociais marcantes é mister que a modernidade foi fazendo seu. Exibí-las, rodeadas por auras de imaginário e de fantástico, qual melhor entre os mundos possíveis, faz parte da sua estratégia, há mais de um século.

As Grandes Exposições recobrem características que favorecem tais intuitos, através de uma certa estratégia de popularização. Implementam-se presenças com cunho (inter)nacionalista. Com elas, é facultada uma representatividade, cada vez maior, para os efeitos económicos, técnicos, científicos ou artísticos, actuando no quotidiano da população mundial, com registos destacados durante as Exposições Universais: Londres $(1851,1862)$, Paris (1855, 1867, 1878, 1889, 1900), Viena (1873), Filadélfia (1876), Barcelona (1888), Chicago (1893), Bruxelas (1897). Elas servem para ilustrar, informar, divulgar as surpresas maiores da produção química e sua aplicabilidade: das indústrias que dependem da Química ao fabrico dos produtos químicos.

A investigação original, diferente das averigações no horizonte da confirmação, materializa-se em Institutos, imponentes até. Os programas de investigação correspondem a núcleos teóricos e sociais que podem transformar grupos em escolas: especificidades entre objectos, métodos e teorias. Os sucessos conseguidos passam pelas fábricas e oficinas. O público apercebe-se disso. Os governos também.

O carácter promissor da Química comporta problemáticas de fundo implicando identidade epistemológica, institucionalidade social e responsabilidade industrial. Neste contexto, as surpresas trazidas pelos avanços da Orgânica e a implementação do modelo saxónico comportam grandes mudanças. Entretanto, o mundo químico e químico-industrial passa cada vez mais a abrigar uma aplicabilidade galopante. Passa a abrigar ainda o reconhecimento e a profissionalização do químico, com estatuto e instâncias de legitimação.

As implicações no ensino - superior e secundário - fazem-se sentir. Deixar de ficar limitado ao espectáculo do anfiteatro, na passividade da escuta e visão, ser autorizado a entrar num laboratório, poder percorrê-lo, dá ao aluno uma experiência da realidade que passa pelas mãos, mesmo se isso pode estar ligado ao preço desumanizante do taylorismo científico ou até à perda da visão global, que se pode vir a pagar pela especialização.

Não se reduza o significado da mudança. É mesmo uma mudança radical, momento avançado de um processo com origem muito atrás: ouvir e ler, transmissão centrada sobre o autor, a autoridade e o comentário, olhar e ver, conhecimento dependendo da via perceptiva e de certo formalismo conceptual, observar e experimentar, inteligibilidade inserida num dispositivo teórico e numa estrutura lógica e matemática. Avanço que os séculos XIX e XX apregoam continuando a tradição "poli-técnica".

Espectroscopia. Radioactividade.
Passam os tempos, os químicos começam a lidar com quantidades de matéria demasiado pequenas para poderem ser pesadas. Algumas das inovações evidenciam a importância da perícia humana. A revolução neutrónica exige grandes mudanças. A big science impõe-se, impondo a necessidade de máquinas sofisticadas, muito dinheiro, gestão pesada, apoios financeiros por parte da indústria, da estrutura militar e da comunicação social. Saber e poder intrincados como nunca se vira antes. Uma nova ruptura vem aí, às portas da Segunda Grande Guerra.

Descrevendo os Laboratórios de Química na Europa entre 1779-1939. esta introdução espera ainda ter contribuído para afirmar como a Filosofia das Ciências permite identificar as condições de existência que possibilitam as relações entre saberes e ciências.

Logo, importa delimitar o modo de ser da instância perceptiva-cognitiva e suas modalidades enunciativas; especificar a táctica operatória actuando no exercício e através do fazer; dilucidar as estratégias em jogo nas práticas, efeitos e produtos obtidos.

Caso particular da maneira como o devir psicológico do conhecimento e o processo histórico contrariam a mesmidade, as relações com o mundo natural e físico não têm tido a mesma identidade e expressão, ao longo dos tempos, colectivos ou individuais.

Com efeito, não só apresentaram, desde sempre, mudanças nos comportamentos e agir, como também representaram vários ritmos no universo teórico e experimental, a partir da modernidade.

\section{ANEXO}

\section{EUROPEAN SCIENCE FOUNDATION PROGRAMME THE EVOLUTION} OF CHEMISTRY IN EUROPE

1

WORKSHOP ON CHEMISTRY

LABORATORIES, INSTRUMENTS, NEW TECHNOLOGIES AND SPACES

(1789-1939)

Segovia, November 1994

Cristalera 
2 WORKSHOP ON CHEMISTRY LABORATORIES, INSTRUMENTS, NEW TECHNOLOGIES AND EDUCATION

(1789-1939)

Lisbon, November 1996

Science Museum of the University of Lisbon

(58, Rua da Escola Politécnica, 1200 Lisbon)

\section{PARTICIPANTES E COMUNICAÇÕES}

\section{SEGOVIA}

Palmira Fontes da Costa and A.M. Nunes dos Santos (P)- A Preliminary Tour on the History of Chemical Laboratories

Natalie Pigeard (F) - Un Alsacien à Paris: Charles Adolph Wurtz (18171884), son Ecole, ses Laboratoires

Raffaella Seligardi (I) - The Laboratory of Giacomo Ciamician at the University of Bologna (1890-1921)

Javier Ordoñez (E) - The Physics and Chemistry Laboratories of the Junta para Ampliacion de Estudios (Madrid, 1907-1938)

Kostas Gavroglu (G) - The Chemical Laboratories and Chemical Education in Cambridge (1853-1914)

Márcia H.M. Ferraz (P) - La Création du Laboratoire Chimique de l' Université de Coimbra à la fin du XVIII.e Siecle

Isabel Garcia Lico (P) - Le Laboratoire de Chimie dans les Lycées Portugais: des Discours Théoriques aux Espaces Pratiques (1886-1936)

Isabel Cruz (P) - The Chemical Laboratory at Lisbon Industrial institute: Paths of Laboratorial Practice in Chemistry from 1864 to 1892

Ana Luísa Janeira (P) - The Chemical Laboratory of the Faculty of Sciences of the University of Lisbon: Organiza- tion of Spaces, Production of Discourses, Epistemological System

Isabel Serra (P) - Professor Branca Edmée Marques and the Radiochemical Laboratory of the Faculty of Sciences of the University of Lisbon

\section{LISBOA}

Luisa M. Dolza (I) - The Dyeing Laboratories of Turin in the Eighteenth Century: History of Their Projects and Failure

Raffaella Seligardi (I) - Teaching Pneumatic Chemistry at the Istituto delle Scienze of Bologna

Paolo Amat di San Filippo (I) Chemistry Laboratories in Sardinia between 1750 and 1850

Virgilio Giormani (I) - La Chimie et ses Applications: Quelques Episodes dans la République de Venise

Mari A. Lires and José Tojo (E) Science and Industry in Galicia During the Enlightenment

Roman Mierzecki (PL) - Experimental Practice and Teaching in Chemistry in Partitioned Poland in XIX c. and After the Regained Independence

David Knight (RU) - Portable Laboratories in the Early 19th Century

Patrice Bret (F) - Laboratoires et Instruments de la Recherche sur les Poudres et Explosifs en France, de Lavoisier à Burlot (1789-1939)

Nathan M. Brooks (EUA) - Chemistry Laboratories in Russia: 1700-1917

Viktor A. Kritsman and Otto P. Krätz (A) - Justus Liebig's Laboratory: Cradle of the Russian Chemistry of the 19th Century

Carlos Alberto Filgueiras (B) The Evolution of Chemistry in Portugal from the 18.th to the 20.th century - an Appraisal

Elisa Maia (P) - The Mineral Chemistry Laboratory of the Polytechnic
School of Lisbon in its Age (1884-1894)

Gabriella Rambaldi and Luigi Cerruti (I) - Cannizzaro's Laboratory Life. The Troubled Making of a New Experimental Tradition, 1851-1862

Francisco Aragón de la Cruz (E) - The Introduction of the Periodic System of the Chemical Elements in Spain

Danielle Fauque (F) - Organisation des Laboratoires de Chimie à Paris sous le Ministère Duruy (1863-1869): Cas du Laboratoire de Chimie de Frémy au Muséum d'Histoire Naturelle

Christoph Meinel (A) - The Research Laboratory and the Teaching of Chemistry in Nineteenth-Century Germany

Rafael Sisto Edreira, M. R. Bermejo Patiño and A. Bugallo Rodríguez (E) - University of Santiago de Compostela Chemistry Laboratory. Creation and Consolidation (1845-1857)

William H. Brock (EUA) - The Chemical Origins of Practical Physics

Gábor Palló (H) - Laboratory Methods on the Peripheries: Radioactivity Measurement Instruments in Hungary at the Beginning of the 20th century

Mudis Salkauskas (L) - Chemistry revival and growth between the two World Wars in Lithuania and other Baltic States

Burghard Weiss (A) - From Arts and Crafts to Big Science: Nuclear Chemistry Laboratories

E - Espanha, G - Grécia, PL - Polónia, RU - Reino Unido, EUA - Estados Unidos da América, B - Brasil, A - Alemanha, $\mathrm{H}$ - Hungria , L - Lituânia P - Portugal, F - França, I - Itália.

\section{PUBLICAÇÕES}

Demonstrar ou Manipular?

O LABORATÓRIO DE QUÍMICA MINERAL DA ESCOLA 
POLITÉCNICA DE LISBOA

NA SUA ÉPOCA (1884 - 1894)

edição bilingue

Livraria Escolar Editora

Lisboa 1996

\section{Conteúdos}

1. A Escola Politécnica de Lisboa (1837-1911):

organização do espaço, produção do discurso e sistema epistémico

Ana Luísa Janeira, Universidade de Lisboa, Agregação em Filosofia das Ciências

2. Semiótica do espaço: o Laboratório de Química

José Augusto Mourão, Universidade Nova de Lisboa, Doutoramento em Teoria Literária

3. O curso prático no ano lectivo de 1889-1890

Maria Luísa Alves, Escola D. Fernando II, Sintra, Doutoranda em História das Técnicas

4. Um director "poli-técnico"

Alexandre Manuel de Oliveira, Universidade de Lisboa, Estagiário em História da Química

5. O final do século XIX português visto através dos 28 anos de vida pública de José Júlio Bettencourt Rodrigues, Ana Maria Cardoso de Matos, Universidade de Évora, Doutoramento em História.

6. Portugal 1884-1894 - ideias e ideários em circulação. Imagens fotográficas de Progresso, Fátima Nunes, Universidade de Évora, Doutoramento em História.

Centro Interdisciplinar de Ciência, Tecnologia e Sociedade da Universidade de Lisboa (CICTSUL)

European Science Foundation Scientific Program on The Evolution of Chemistry in Europe
Space Organisation and Production of the Scientific Discourse: Chemistry Laboratories in Portugal

Divórcio entre Cabeça e Mãos? LABORATÓRIOS DE QUÍMICA EM PORTUGAL (1772-1959) edits.: Estela Guedes, Pedro Sousa Dias, Raquel Gonçalves

edição multilingue Livraria Escolar Editora Lisboa 1998

\section{Conteúdos}

\section{Introdução}

P - texto de Raquel Gonçalves 1

P - O Laboratório da Casa da Moeda de Lisboa - Márcia Ferraz

P - Le Laboratoire de Chimie de l'Université de Coimbra - Márcia Ferraz

P - texto sobre relações entre Química e Farmácia - Pedro Sousa Dias

P - síntese - texto de Ana Cardoso de Matos

\section{2}

F - Les Laboratoires de Chimie dans les lycées portugais: des discours théoriques aux espaces pratiques (1836-1936) - Isabel Lico

E - Permanência ou mudança : que lugar para a prática laboratorial de Química no primeiro liceu português? - Isabel Lico

I - The Chemistry Laboratory in the Instituto Industrial de Lisboa (1869-1898) - Isabel Cruz

E - O Laboratório Químico do Instituto Industrial de Lisboa: conflitos entre ensino e produtos da ciência aplicada - Isabel Cruz

P - síntese - A Química em Institutos Industriais e Liceus portugueses: acções e intenções (1836-1892) Isabel Cruz e Isabel Lico

$$
3
$$

P - texto sobre Laboratório de Química na Universidade de Coimbra - Amorim da Costa

I - O Laboratório de Química da Escola Politécnica de Lisboa - Elisa Maia
P - Os Laboratórios de Química nas Politécnicas portuguesas. A Filosofia inerente aos discursos regulamentares - Ana Luísa Janeira

P - Análise semiótica de um espaço laboratorial: o Laboratório $\mathrm{Mu}$ nicipal de Química do Porto (18841907) - Isabel Marcos

I - O Laboratório de Química da Faculdade de Ciências de Lisboa: organização do espaço, produção do discurso e sistema epistémico - Ana Luísa Janeira

I - Branca Edmée Marques e o Laboratório de Radioquímica da Faculdade de Ciências de Lisboa Isabel Serra

P - Os Laboratórios de Química do IST (1911-1955) - M. Berberan e Santos, Miguel Castanho

Conclusão

I - The Evolution of Chemistry in Portugal from the 18 th to the 20th century - an Appraisal - Carlos Alberto Filgueiras

$\mathrm{E}$ - inglês, $\mathrm{F}$ - francês, $\mathrm{P}$ - português

- Coordenadora, com o Professor Javier Ordoñez, da secçào Chemistry Laboratories, Instruments and New Technologies do European Science Foundation Programme The Evolution of Chemistry in Europe (1789. 1939), no âmbito do qual se realizaram os Workshops de Segóvia e Lisboa, onde foram apresentados os textos, asinalados em anexo.

Professora Associada do Departamento de Química e Bioquímica da Faculdade de Ciências da Universidade de Lisboa

Rua Ernesto de Vasconcelos, 1700 Lisboa tel. 351.1.7573141, fax 351.1.7500088

Coordenadora Científica do Centro Interdisciplinar de Ciência, Tecnologia e Sociedade da Universidade de Lisboa (CICTSUL)

Rua da Escola Politécnica 56, 1200 Lisboa

tel 351.1.3961521/2/3 fax 351.1.3909352

1 Comunicação apresentada no EUROPEAN SCIENTIFIC PROGRAMME ON EVOLUTION OF CHEMISTRY IN EUROPE, FINAL CONFERENCE, Delfos, 1997 e na $V$ REUNION HISTORIA DE LA MATERIA MÉDICA: EUROPA-AMÉRICA, Buenos Aires, 1997.

2 Enquanto nào forem publicados nos Estados Unidos da América, o que acontecerá brevemente, estes textos podem ser consultados no CICTSUL

3 Seligardi $1=$ texto apresentado em Lisboa

Seligardi 2 = texto apresentado em Segóvia. 